\title{
Vedic System Of Management: Perfect Alliance Of Life Style And Administration Ipsit Pratap Singh
}

\begin{abstract}
Management is a key driver of the mass psyche today. Time management, team management, Fiscal management, relationship management, career management - thus life moves on for each thinking human being on the planet. But this template of management has brought in its own woes of stress, anxiety, psychosis and other host of sicknesses and diseases. Modern research is exploring the path of Vedic Management which pivots on the concept of a holistic living, rooted in Universal compassion and care. This paper explores the concept of Vedic Management with thrust on modern management principles in combination with the Vedic wisdom of life regulation.
\end{abstract}

Key words. Management, Universal compassion, Vedic Management, Vedic wisdom 


\section{Introduction}

The study of Vedic Civilization keeps unraveling new elements during the course of its ongoing study by the archaeologists and Indologists. It is assumed; Vedic civilization followed the Indus Valley Civilization. Previously some western historians denoted the Vedic people were barbarians who destroyed the earlier existing civilization and built up their own. Modern research indicates nothing of this sort and points out destruction through natural ravages as frequent flooding and other natural disasters of the time. Kenneth Kennedy has been vocal about the debate regarding the decline of Indus Valley Civilization discounts the previous assumption based on Sir Mortimer Wheeler's theory that held Indus Valley civilization as ending in massive aggression. He stated it while he discovered a group of 37 skeletons found in various parts of Mohenjo-Daro, and passages in the Vedas referring to battles and forts. The Vedic period (or Vedic age) (ca.1750-500 BCE) was the period in Indian history during which the Vedas, the oldest scriptures of Hinduism, were composed. During the early part of the Vedic period, the Indo-Aryans settled into northern India, bringing with them their specific religious traditions. The associated culture (sometimes referred to as Vedic civilization was initially a tribal, pastoral society centered in the northwestern parts of the Indian subcontinent; it spread after 1200 BCE to the Ganges Plain, as it was shaped by increasing settled agriculture, a hierarchy of four social classes, and the emergence of monarchical, state level polities. The end of the Vedic period witnessed the rise of large, urbanized states as well as of shramana movements (including Jainism and Buddhism) which challenged the Vedic orthodoxy. Around the beginning of the Common Era, the Vedic tradition formed one of the main constituents of the so called "Hindu synthesis" (Ajithkumar, M.P. - 2013).

\section{Vedic Life - Some concepts}

Individual Soul (JeevanAtma) is the reflection of the Cosmic Soul (Paramatma). I am the reflection of the Cosmic Soul, and every Individual Soul is actually inbuilt with the quality of expansion, so that it can become the Cosmic Soul. This is the spiritual journey of every individual soul on planet earth. We are all spiritual beings having a human experience, not human beings having a spiritual experience. From Upanishad (the secret teachings of Vedas), it is the Cosmic Soul that exists in all lives. When we can see the same Spirit in others, we drop the fear because we understand that we are all one. We are the source, a part of the Universal Spirit or Supreme Consciousness.

\section{Food}

The Vedic tradition advocates Sattvic vegetarian food because this diet uses the least from nature and it does not cause destruction or imbalance in nature and the living creatures. In addition, vegetarian diet has a stabilizing effect on our consciousness and it is easy on the digestive system. Ancient masters, sages and rishis found that man gets energy directly when he feeds on vegetables and fruits. What we consume influences our behavior and thinking, the vital energy from non-vegetarian food is of secondhand since one consumes "dead second-hand food". Hence, food that is either Rajasic (stimulating) or Tamasic (impure) should be avoided. The fascinating truth is Vedic science even gives us the choice of living without food. This can be achieved through a yogic process called NiraharaSamyama by which we learn to awaken our bio memory to produce energy from prana, water and sunlight, just like plants or trees. 


\section{Spiritual practices}

In Vedic traditions, spiritual practice is the life. This body is the temple of the Cosmic Soul; it is through the body that we are able to experience the Cosmic Soul. That is the reason that in the Vedic tradition, spiritual practices (Sadhana) is so important because it is through regular practice that we are constantly reminded of our original state of pure consciousness and we are able to connect with the Source. Many people seek the spiritual knowledge but they don't practice in their life. This is equivalent to wasting life because it is through practice that transformation happens. Everything in life is nothing but spiritual practice. The different spiritual practice of Kriya, Hatha Yoga and Pranayama, Samyamas prepare our body-mind to sit with ourselves in meditative state so that we can align the body-mind to connect with Cosmic Consciousness. This practice helps to start the day in a state of awareness (Singhal, K.C. - 2003).

\section{Guru and Oneness}

In Vedic lifestyle, "Guru, God and Self are ONE”. The word 'guru' means 'one who dispels darkness'! A guru or a master represents a new possibility in our life. He is a new consciousness in our being. He gives us the thirst for truth. He never fails to give inspiration and he opens the doors of possibility whenever we are stuck in life. Some people say they don't need a master. As of now, our inner light is unlit, by coming close to a master, he lights our inner flame and spurs us to become alive! Once the inner light happens, it starts radiating until it merges with the flame that surrounds it, then there are no longer 2 entities, there is only ONENESS. That is why devotion to Guru (Bhakti Yoga) is the fastest route to Self Realization as a Sadguru is one who leads you to liberation.
In Vedic lifestyle, life is a continuous expansion. Every day every moment life is teaching us something about its grandeur. The way a master continues to inspire us is through satsang which is the company of highest truths with guru.

Since we are the source, anything we see is an extension of self. Anything and anybody we experience is an extension of self. All relationships are an extension of self and any suffering from relationship is a sign of incomplete part of one self. In Vedic tradition, everyone is moving towards ultimate space of consciousness. When we enrich them, part of us is also enriched. When they feel completion, part of us will feel complete. All relationships are meant to bring completion in us and lead us to fulfillment. This is one of the greatest things which we should imbibe.

\section{Conscious Death or Deathlessness}

In Vedic tradition, the concept of death is very mystical. Death can be used as a jumping board to the enlightenment if you know how to prepare your body-mind while in the body. This vedic science gives us the choice of having a conscious death while exiting the body gracefully or deathlessness. All these spiritual sciences (spiritual practices) are available to humanity if we are interested to explore with the right master (Pargiter, F.E. - 2012).

\section{Society in Vedic Civilization}

The society during the Vedic Civilization was patrilineal in structure and benevolent towards women. Women were honored both inside and outside their homes. The Vedic people generally practiced the concept of joint families. At the same time girls got the opportunity to educate themselves along with the boys and took the lead in life too. The male and female progeny carried the responsibility of leading a life of 
Dharma - a value based life, hence it was the duty of each parent to be concerned about the intellectual achievements of one generation and take suitable steps to initiate them to the Vedic literature.

In Vedic Civilization there were distinctions of classes loosely based on profession. The four classes which were part of the Vedic society were the Brahmins, Kshatriyas, Vaishya and the Sudras and there were certain boundaries with regard to professions. A method of ashram system prevailed in the Vedic era. Four ashrams of Vedic Life were included and it was done with a view to offer proper ideas on both Karma and Dharma. The ashrams of the Vedic society were categorized as Brahmacharya, Grihastha, Vanaprastha and Sannyasa. The fact that caste system was not present in the Vedic society can be well understood because it was customary for all boys and girls of the Vedic era to undergo the ceremony of 'upanayana', unlike the present age where only a particular class of the society practices the thread ceremony. In the Vedic Age, like boys, the girls also had to lead a life of brahmachari. Hence, there was not much difference in the treatment of girls and boys during the Vedic period.

Social life in Rig Vedic Civilization was characterized by a nomadic lifestyle by some historians. However, the later studies revealed that Vedic Civilization was quite different and very much developed. The later Vedic Period came to be known as the Epic Age. Social life during the Vedic period included large selfsustained settlements, fortified and protected by warriors.

\section{Vedic literature}

Vedic Literature which was mainly the Vedic Samhitas or the Mantras and the metric texts emerged during the Vedic period. Vedas are a collection of four parts, namely, the Rig Veda, Sama Veda, Yajur Veda and the Atharva Veda. The Vedic literatures are the earliest forms of literary works in India. It consists of the Samhitas, the Brahmanas, the Upanishads and the Aryanakas. These forms of Vedic literature till today are held in high esteem by the Indians especially the Hindus. During this period music was much developed. Various musical instruments were used to produce melodious tones and the beautiful music was accompanied by skilled dance performances. Apart from the artistic accomplishments, the Vedic Civilization is well known for the ancient science of Ayurveda which stands as a heritage of India today. The practice of using nature as a system of healing and rejuvenation is as old as the Vedic Civilization itself. Even recently elements from the ancient Ayurveda are being used to cure certain diseases of both the mind and the body (Raichaudhry, Hemchandra 2012).

\section{Sources to study Vedic period}

The Vedic Period or the Vedic Age refers to that time period when the Vedic Sanskrit texts were composed in India. The society that emerged during that time is known as the Vedic Period, or the Vedic Age, Civilization. The Vedic Civilization flourished between the $1500 \mathrm{BC}$ and 500 BC on the Indo Ganges Plains of the Indian subcontinent. This civilization laid down the foundation of Hinduism as well as the associated Indian culture. The Vedic Age was followed by the golden age of Hinduism and classical Sanskrit literature, the Maurya Empire and the Middle Kingdoms of India (Jha, D.N. 2006).

\section{Vedic Texts}

Linguistically, the texts belonging to the Hindu Vedic Civilization can be classified into the following chronological branches. 
Rigvedic: It is believed that the compilation of the Rig Veda had stretched over a number of centuries. However, there is a conflict as to the completion date of the Rig Veda. Some historians believe it to be $1500 \mathrm{BC}$, while the others believe it to be 3000 BC (Sharma, R.S. 1999).

Mantra Language: The period of the Mantra Language includes the time of the compilation of the mantra and prose language of the Atharvaveda (Paippalada and Shaunakiya), the RigvedaKhilani, the SamavedaSamhita and the mantras of the Yajurveda. Though derived from the Rig Veda, all these texts experienced wide scale changes, in terms of language as well as at the time of reinterpretation (Kannan, S. 2009).

Samhita Prose: The period of Samhita Prose represents the compilation and codification of a Vedic canon. The commentary part of the Yajurveda belongs to the Samhita Prose period (Kannan, S. 2009).

Brahmana Prose: This period signifies Brahmanas proper of the four Vedas, along with the oldest Upanishads.

Sutra Language: The last division of the Vedic Sanskrit can be believed by some to be traced upto 500 BC. During this time, a major portion of the Srauta Sutras, the Grihya Sutras and some Upanishads were composed.

Epic and Paninian Sanskrit: In the post Vedic Period, the compilation of Mahabharata and Ramayana epics took place. The Classical Sanskrit described by Panini also emerged after the Vedic Age. The Vedanta and the PaliPrakrit dialect of Buddhist scripture belong to this period. The end of the Vedic Period Civilization in India was marked by significant changes in the field of linguistics, culture and politics. With the invasion of the Indus valley by Darius I, in the 6th century, outside influences started creeping in.

Early Vedic Period (Rigvedic Period): The Rigvedic Period represents the time period when the Rig Veda was composed. The Rig Veda comprises of religious hymns, and allusions to various myths and stories. Some of the books even contain elements from the preVedic, common Indo Iranian society. Some similarities are also found with the Andronovo culture and the Mittanni kingdoms. Thus, it is difficult to define the exact beginning of the Rigvedic period (Sharma, R.S. 1999).

\section{Vedic life style management}

Human mind always calculates that what could be the probable differences between today's life style and at Vedic ages. Vedic scriptures say there are some basic mobility factors that make a lifestyle Vedic. Vedic time is the era of Vedas, at that time people where known as rishis who had different routines plans to carry on: the early morning woke up, then yagya ceremony, daily devotional prayers to god, prayers were gratitude towards god. Vedic people were more conscious towards their work they do in daily life, focusing upon the best outcome with excellence in action so in other word we can call it as conscious living.

It is believed that doing any work or action regularly makes you more aware and excellent on that work, similar was the lifestyle of vedic seers and sages. People focused on perfection of work to achieve the highest level of excellence. Providing or discussing more about Vedic ages may create some dialogues difference; summarily, Vedic style of living is "early to bed early to rise make a man healthy wealthy and wise" is "Yoga karmashukaushalam". So if we follow the Vedic scripts in modern form our 
lifestyle may become more filled with righteousness.

"Wake up and run" this is the mantra to join the fast moving outer world; now a days, people are turning more conscious towards their health issues, they are doing regular yoga, performing exercises, spending their time at gym halls, or aerobic classes. But the difference comes when one don't find satisfaction in physically fit lifestyle. So the question arises, where is the problem? Answer to this is very much simple, we need Vedic lifestyle, and as we depicted that Vedic style is conscious living. And consciousness starts with thoughts. So first we need to focus more upon our thought process. As the chain of social psychology in indigenous way says that - 'thoughts makes words, words makes action, actions makes behavior, behavior makes character and finally character makes personality'.

\section{Adopting some Vedic practices}

Adopting Vedic practices such as waking up early can give quality time to spend for self i.e. performing meditation of different forms to concentrate more upon own body, and observing own thoughts, actions and behavior for the day. In such practice, it is needed to believe that you are the whole sole controller of your body; mind and thoughts with deep breathing making you feel your presence in our own world. These are some of the divine teachings of Vedic lifestyle that each and every individual should follow in regular life.

'Give space to your cultural as well as cross cultural thoughts': this is most important aspect of Vedic philosophy that spirituality means give and take.
'Start acting with moral thoughts': It has been always a talk on good thoughts but vedic traditions implies to stop talking and thinking about moral behavior and to start acting on it.

'Start making your own boundaries to evil': Every person is with error, but giving space to error is spirituality. Management also says that we always should give some space to humans for performing errors because realizing error can lead them towards correction and perfection.

'Time for family is more important': Everybody needs emotional support. Family is a place from where one starts and ends journey.

\section{Vedic Administration}

The administrative machinery of the Aryans in the Rig Vedic period worked with the chief in the centre. He was called rajan. Although his post was hereditary, we have also evidences in literature indicating election by the assembly called the samiti. The king was called the protector of his kindgdom. Several assemblies, such as sabha, samiti, vidatha, and gana mentioned in the Rig Veda exercised deliberative, military and religious functions. Even women attended the sabha and vidatha in Rig Vedic times. In addition, from the political point of view, important were the sabha and samiti in the day to day administration, the king was assisted by a few functionaries. The most important functionary seems to have been the purohita who were of the level of Rishis. The two priests who played a major part in the time of Rig Veda were Vasishtha and Visvamitra. The next important functionary seems to be the senani (commander).

Vedic literature is mystic. It uses symbols for inner journey i.e. cows, horses etc were symbols of spiritual forces helpful for the consciousness 
elevation. However, in the present study, the symbols were also taken to predict the socialpolitical view of the vedic time which is described further. In Vedic literature, there were cases of theft and burglary, and especially the theft of cows. Spies were employed to keep an eye on such unsocial activities. The officer who enjoyed authority over the pasture ground was called vrajapati. He led to the heads of the families called Kulapas or the heads of the fighting hordes called gramanis to battle. The king did not maintain any regular or standing army, but in times of war he mustered a militia whose military functions were performed by different groups called vrata, gana, grama, sardha. The chief was the protector of the people or Jana. However, he did not possess unlimited powers for he had to reckon with the people assemblies Sabha, Samiti, Vidhataand Gana were the tribal assemblies. Of these, Vidhata was the oldest. These assemblies exercised deliberative, military and religious functions. The two most important assemblies were the Sabha and Samiti. Samiti was general in nature and less exclusive than Sabha (Habib, Irfan, 2012).

\section{Alliance of life style and administrative system}

Administration cannot run on only utopian ideology. It must have sharp connection with the culture and life style of people. Indian administrative system is bearing the load of British imposed system. India has wonderful scriptures which have guides the world since centuries. India needs to readopt its Vedic traditions to revive the golden age described to that of Vedic India. The ancient scriptures of India like - Vedas, Puranas, Samhitas, Upanishads have amazing methods of life style and administration. Every region of the world has different demands in terms of everything whether it is life style management or administrative system. In Vedic era, one can find the perfect alliance of life style and administration. People were active for the benefit for their society. The real democracy was there alike today. Today people just have a right to vote but we they don't have any right to take decisions for national benefit. In Vedic era the community was there to take each and every step not a single person was allowed to do autocracy. Indian social system can flourish in better way if the Vedic model would reimplement in nation.

Today many organizations are working for women empowerment. But in Vedic society, one can easily find ideal place for women. Vedic system has given equal rights and respect to women where reputed people gave opportunities to women for their growth. The Vedic system teaches not only educating women but empowering women by awakening the true potential and qualities of womanhood for themselves and society. By providing mere freedom won't bring the real need of women empowerment. What we can exact learn from Vedic system in the perspective of women empowerment is we should provide them 'Vidya' for the building of our nation. As we know well that an ethically educated and spiritual woman can make her family moral and spiritual, and family is the most important unit for any nation.

Many European scholars blame Vedic society for discrimination with in society. But researches have proven that Vedic society followed 'varnvyavastha' (system based on personality) not 'jativyavastha' (system based on birth caste). The discrimination was based on work not birth. Work based discrimination is positive for any society because it brings positive competition within people. Vedic society made ideal 
combination of society and administration which made easier way to govern. This alliance of life style and administration make ideal system. Thus, Vedic systems of worship, governance and social engineering are very contextual in today's scenario (Bhargawa, Purshottam, 2001).

\section{Conclusion}

Though it is impossible to adopt everything from Vedic way of management, there is a big scope of adaptation from Vedic administrative system which is efficient and culture based. Vedic society not only taught spirituality but also taught all aspects to the world varying from scriptures, life style, society, management and administration, etc., which are equally relevant today. For present system of administration, there is a lot to learn from Vedic society, which cared for each individual, whereas we are living in $21^{\text {st }}$ century, but system at globe has still has to work hard to serve the last man of the society.

Ipsit Pratap Singh. Department of Indian Culture and History. Dev Sanskriti University, Haridwar, India. Email- ipsit.singh@dsvv.ac.in

\section{References}

Ajith kumar, M.P., Vedic India : A History, Kalpaz Publication, Delhi.

Kannan, S. (2009), Vedic Management, Taxmann Publications Private Limited, New Delhi.

Saigal, Krishnan (2000), Vedic Management ,Gyan Publishing House, New Delhi.

Pargiter, F.E. (2012), Ancient Indian Historical Tradition, Forgotten books Publication, Chaeleston USA.

Singhal, K.C. (2003), The Ancient History Of India (Vedic Period), Atlantic Publication, New Delhi.

Raichaudhry, Hemchandra (2012), Political History of Ancient India, from the Accession of Parikshit to the Extinction of the Gupta Dynasty, Forgotten books Publication, Chaeleston USA.

Jha, D.N. (2006), Ancient India in Historical Outline, Manohar Publishers and Distributors, New Delhi.

Sharma, R.S. (1999), Ancient India (Ncert).

Bhargawa, Purshottam (2001), India In The Vedic Age, D.K. print world, New Delhi.

Habib, Irfan (2012),The Vedic Age , Tulika books, Delhi. 